\title{
References
}

1. Blagoy, D. (2000). Selected articles about music. Moscow: Humanitarniy centr «MONOLIT» [in Russian].

2. Sokol, A. (2007). Performing remarks, image of the world and musical style. Odesa: Moryak [in Russian].

3. Feinberg, S. (1969). Piano performance like an art. Second edition. Moscow: Muzyka [in Russian].

4. Venable, M. (1913). The interpretation of piano music. Boston, Oliver Ditson Company. [in English].

УДК 78.036:78.071 Лютославський

DOI: https://doi.org/10.33643/kmus.2019.59.02

Ольга Мироненко-Міхейшина, аспірантка кафедри теорії музики Національної музичної академії України ім. П. І. Чайковського https://orcid.org/0000-0002-7271-848X mimollka@ukr.net

Olha Myronenko-Mikheishyna, Postgraduate at the Theory of Music Department, Ukrainian National Tchaikovsky Academy of Music https://orcid.org/0000-0002-7271-848X mimollka@ukr.net

\section{ЗМІСТ ЯВИЩА АКЦЕНТУ В СУЧАСНІЙ МУЗИЦІ (НА МАТЕРІАЛІ ТВОРІВ ВІТОЛЬДА ЛЮТОСЛАВСЬКОГО)}

У статті розглядається явище акценту в сучасній музиці (особливості функціонування, властивості) на матеріалі композицій В. Лютославського. Актуальність дослідження зумовлюється відсутністю в сучасному музикознавстві системного аналізу особливостей функціонування акценту в новітній музиці. Головною метою є з'ясування змісту явища в сучасних композиціях через аналіз творів В. Лютославського (Віолончельний концерт, «Три поеми Анрі Мішо»). У результаті дослідження виявлені такі форми явища, як сфокусований акцент (сумарний точковий та поодинокий точковий) та несфокусований (розмитий), а також з'ясовані його властивості та функції.

Ключові слова: акцент, часова організація, поліхронність, Віолончельний концерт В. Лютославського, «Три поеми Анрі Мішо» В. Лютославського. 
Myronenko-Mikheishyna Olha. The content of the accent's phenomenon in the contemporary music (on the materials of the works by Witold Lutosławski). The subject of the study. The present study examined the phenomenon of accent in the contemporary music (the features of functioning, the properties) on the material by W. Lutosławski's works. Relevance of the study. Relevance of the study is caused by the absence of systematic, complex study in musicology of the accent's features in the contemporary music. Besides there are no studies in the mentioned aspect devoted to the W. Lutosławski's works - «Trois poèmes d'Henri Michaux» and Cello Concerto. Main objective of the study. The goal of the study consists in determining the content of accent's phenomenon in the contemporary music compositions by the way of analysis of W. Lutosławski's works. Methodology. The research is based on the comparative, the structural, the system and the functional methods. Results. As a result of research, the following forms of the phenomenon were identified: the focused accent (multipoint and single-point) and unfocused (blurred). It turned out that the formation of the point accent is conditioned by the combined action of elements and means of the musical language (melody, rhythm, harmony, texture, dynamics, agogic, articulation, stresses in the verbal text) and by the action of such basic principles of musical form as similarities and contrasts. An additional accent-forming mean is the euphony of the verbal text. It is investigated that the initial moment of sound attack is not important for the point accent's forming. But for the blurred accent the initial moment of sound attack is unrequired: the underlining can form gradually. The highest degree of the textural densification, the register expansion or narrowing, the dynamic and agogistic «chromatization» and underlining through the similar by quality timbre are factors of the «blurred accentuation» in the micro-polyphonic sonoristic structures. Analysis of the point and blurred accents' features of functioning allows to talk about an extended set of the phenomenon's properties: the composite nature, the non-measurability, the different and relative measure of weight, the varying degrees of the tension, the different degrees of the phenomenon's revealing, the possibility of a modulation from one accent's form to another, the possibility of the synchronous interaction of the different forms, the relative duration of the accent's tension spreading. The accent can be determined as an autonomous rhythmic element in the regular-metric fragments and as a resultative in the unregular, aperiodic segments. It is analized that an accent is the factor of the dismemberment of the time stream into the discrete parts and combining the several rhythmic units into «entirety», the factor of the pulsation's forming, the effects of rhythm-statics, rhythmdynamics, polychronism. Significance. The examined forms, properties and 
functions of accent in the the works of W. Lutosławski allow to extend the apprehension of the phenomenon and to determine its content from the standpoint of the rhythm theory.

Key words: accent, temporal organization, Cello Concerto by W. Lutosławski, «Trois poèmes d'Henri Michaux» by W. Lutosławski.

Мироненко-Михейшина Ольга. Содержание явления акцента в современной музыке (на материале произведений Витольда Лютославского). В статье рассматривается явление акцента в современной музыке (особенности функционирования, свойства) на материале сочинений В. Лютославского. Актуальность темы обусловлена отсутствием в современном музыковедении системного, комплексного исследования особенностей данного явления в новейших музыкальных композициях. Помимо этого, не изучены в обозначенном аспекте сочинения В. Лютославского - «Три поэмы Анри Мишо» и Виолончельный концерт. Главная цель состоит в том, чтобы выяснить содержание явления акцента в современных музыкальных композициях путем анализа произведения $\quad$ В. Лютославского. Исследование основывается на компаративном, структурном, системном и функциональном методах. $\boldsymbol{B}$ результате анализа обнаружены такие формы явления, как: сфокусированный акцент (единичный точечный и суммарный точечный) и несфокусированный (размытый). Выяснилось, что формирование точечного акцента обуславливается комплексным действием элементов и средств музыкального языка (мелодикой, ритмикой, фактурой, динамикой, агогикой, артикуляцией, ударениями в словесном тексте), а также действием всеобщих формообразующих принципов повторности (синтаксических структур с идентичным внутренним устройством) и обновления (изложения музыкального материала). Дополнительным акцентообразующим средством является инструментовка вербального ряда. Обнаружено, что в образовании точечного акцента важную роль играет начальный момент атаки звука, в то время как для размытого он вовсе необязателен: выделение может сформироваться постепенно. Фактором «размытого акцентирования» внутри микрополифонического сонорного комплекса является наиболее высокая степень: фактурного уплотнения голосов, расширения регистра, динамической или агогической «хроматизации», а также - подчеркивание близким по качеству тембром. Анализ особенностей функционирования точечного и размытого акцентов позволяет говорить о расширенном комплексе свойств явления: комплексность, неизмеримость, многосоставность, разная и относительная степень тяжести, разная степень напряжения, разная степень четкости выявления акцента, возможность 
модуляционного перехода от одной формы акцента к другой, возможность синхронного взаимодействия разных форм, относительная длительность распространения действия напряжения акцента.

Выяснилось, что акцент является автономным ритмическим элементом в случае его функционирования в равномерно-регулярных эпизодах и результативным в условиях неравномерной регулярности, апериодичности. В произведениях Лютославского акцент является фактором расчленения временного потока на дискретные составляющие, объединения нескольких ритмических единиц в «целосность», образования пульсации, формирования художественных явлений ритма-статики, ритма-динамики, полихронности. Проанализированные формы, свойства и функции акцента в произведениях В. Лютославского позволяют расширить представление о явлении и определить его содержание с позиций теории ритма.

Ключевые слова: акцент, временная организация, Виолончельный концерт В. Лютославского, «Три поэмы Анри Мишо» В. Лютославского.

Особливості явища акценту вже детально розглянуті в музикознавстві. Проте, властивості й функції цього фундаментального елементу ритмічної системи в музичному матеріалі творів XX-XXI ст. набувають нових характерних якостей, які ще не з'ясовані достатньою мірою в сучасній теорії. Зокрема, нетиповою та майже недослідженою $є$ акцентність у творах В. Лютославського - Віолончельному концерті та «Трьох поемах Анрі Мішо». Це зумовлює необхідність уточнення змісту явища на основі аналізу обраних композицій. об'єктом уваги є явище акценту в новітній музиці, предметом - його властивості, метою дослідження - 3'ясування його змісту в сучасних музичних композиціях через аналіз творів В. Лютославського. Головні завдання полягають в: аналізі партитурних текстів у зазначеному аспекті, вивченні музикознавчої літератури під кутом зору окресленої проблематики, визначенні з позицій теорії ритму властивостей явища акценту та механізмів його утворення й функціонування у творах В. Лютославського.

Задля 3'ясування сучасного стану знання про предмет дослідження найперше ми звернулися до словниково-енциклопедичних матеріалів, виданих у різні роки: від 1901 р. («Словник» Г. Рімана [14]) до 2001 р. (Музична енциклопедія Гроува [18]). Порівняння статей з різних джерел дозволило дійти висновку, що i усвідомлення значення акценту, i термінологія у висвітленні цього явища суттєво змінилися протягом значного проміжку часу. Якщо розуміння сутності акценту та його змісту віддзеркалюється в словникових статтях різних часів у близьких, подібних 
визначеннях (акцент як виділення [21, с. 806], вирізнення звуку [13, с. 20; 18 , с. $20 ; 15$, с. 40$]$, «наголошування; посилене, наголошене видобування певного звуку» [4, с. 11], «виділення <..> через посилене наголошення» $[14$, c. 18]), то інші аспекти опису явища потребують окремого коментаря. Наприклад, у «Словнику» Рімана [14] акцент характеризується тільки під кутом зору засобів його утворення, а в Енциклопедичному словнику Гроува-1995 [21] феномен охоплюється дуже широко, характеризується відповідно до ієрархії ритмічних явищ та функції цього елементу в ритмічній системі в цілому: «тривалість та виділення (stress) - іншими словами, конструкції у часі та градації у силі $-\epsilon$ центральними детермінантами ритму, його конститутивними факторами» [21, с. 806] (розрядка моя. - О. М.). Ця цитата не тільки є поштовхом для розмірковувань 3 приводу концепційного узагальнення змісту явища, але й свідченням глибокого переосмислення місця та ролі акценту в ритмічній системі. Наприклад, у «Словнику» Рімана [14], Енциклопедії музики під ред. А. Ходковського [18], Енциклопедичному словнику під ред. Г. Келдиша [13] акцент характеризується як самостійне явище, пов'язане 3 різними елементами музичної мови: мелодикою (мелодичний акцент), артикуляцією (артикуляційний), динамікою (динамічний), ритмікою та метрикою (ритмічний, метричний) тощо. У виданнях Гроув-1995 [21] та Гроув-2001 [20] феномен характеризується і як самостійне явище, і як окремий складник ритмічної системи. Зокрема, в Музичній енциклопедії Гроува-2001 [20] у параграфі «Ритмічний та метричний акцент» зі статті «Ритм» [19] міститься огляд різних авторських концепцій явища в аспекті теорії ритму, термінологічних дискусій стосовно змісту понять метричного, ритмічного акценту (metric accent, rhythmic accent) та стресу, тобто виділення (stress). Ми не коментуємо авторські положення через відсутність джерел, проте посилаємося на цей матеріал задля повноцінного відтворення ступеня вивченості явища на сучасному етапі. Нарешті, цікавою $\epsilon$ i розбіжність в історичних назвах типів акценту: початковий, мелодичний, граматичний - або позитивний («Словник» Рімана [14]) та, наприклад, мелодичний, артикуляційний, динамічний, звуковисотний, гармонічний - в сучасних словникових виданнях. Ця розбіжність суттєво не змінює погляд на явище, проте розширює уявлення про його історичне побутування.

Серед авторських теоретичних праць, присвячених проблематиці, засадничими на сьогодні $\epsilon$, насамперед, розробки $\mathrm{B}$. Холопової та Н. Афоніної, в яких найбільш систематично i, водночас, проблемно висвітлюється специфіка феномену. За В. Холоповою, «сутність акценту як специфічно музичного явища полягає в тому, що він створюється усіма 
елементами й засобами музичної мови - інтонацією (інтонаційна напруга), мелодикою (підйоми та спади мелодичної лінії), гармонією (зміни гармоній, функціональне наповнення та фонічна барва гармоній), ритмічним малюнком (більші тривалості, які іноді заповнюються активним дробленням), фактурою (щільний акорд, глибокий бас), тембром (зміни тембру, більш інтенсивні темброві комплекси), словесним текстом (склади тексту, ударні склади), агогікою (незначне уповільнення в зоні акцентованого звуку), динамікою (посилення гучності)» [16, с. 132-133]. У цій характеристиці розкривається суттєва особливість акценту комплексна природа, а також виявляються та систематично узагальнюються чинники його утворення. Н. Афоніна відмічає ще одну важливу властивість явища - його принципову незмірність: «Відносність акценту виявляється тільки у порівнянні, вона подібна до кількісної відносності довготи, з тією відмінністю, що акцентність як ознака якісної відмінності ритмічних одиниць $є$ принципово незмірною: хоча в тактовому метрі вона утворює аналог "кількісної шкали" (тактові, дольові та внутрішньодольові метричні акценти різної “ваги”), а у власне ритмічній матерії акценти зіставляються один 3 одним тільки за типом “більш інтенсивний - менш інтенсивний”» [2, с. 30]. Дослідниця також чи не першою порушує питання функцій явища: на думку науковця, акцент $є$ чинником розчленування часового плину на дискретні частки та, водночас, об'єднання декількох ритмічних одиниць у «цілісності ритмічного малюнка» [2, с. 31]. Крім цього, науковець зазначає: «Акцентність розшаровує ритмічні одиниці в їх послідовності на головні, підлеглі, опорні та неопорні. Таким чином, акцентність виявляється більш складною властивістю ритмічних елементів, ніж їх тривалість. Проте обидві властивості, як різні сторони одного явища, існують тільки у взаємодії одна 3 одною» [2, с. 13]. Н. Афоніна також пропонує одне з найгнучкіших, хоча й не цілком вичерпних визначень явища: «Акцент - це підкреслення ритмічної одиниці в ряду інших через зміну її властивостей» [1, с. 11], а також чітко визначає його головний зміст: подразнення (під кутом зору психології сприйняття), наголошування (під кутом зору мовлення) [2, c. 11]. Продовжуючи думку дослідниці, можна додати також до цього ряду й виділення звуку (в музиці).

Отже, підсумуємо, що в наявних доступних на сьогодні дослідженнях узагальнюються засадничі властивості акценту, його функції в ритміці та засоби утворення. Проте, наведені теоретичні положення не дозволяють системно, повно пояснити особливості акцентної організації в творах В. Лютославського, зокрема - механізми акцентуації в тих 
фрагментах, де виникають художні ефекти часової статики, полічасового нашарування. Це зумовлює актуальність дослідження.

Аналіз творів В. Лютославського в обраному аспекті ускладняється, передусім, через те, що графічне оформлення музичного матеріалу в обраних композиціях викликає почасти асоціації з класичною акцентністю: метрично нерегулярні епізоди мають в нотах тактовану та метризовану фіксацію. Проте, насправді такий запис, спрямований на полегшення репетиційної роботи, є умоглядним і абсолютно суперечить слуховим враженням. У зв'язку з цим аналіз акцентності в музиці В. Лютославського потребує неодмінної координації результатів «зорового» аналізу із враженнями слухового сприйняття. Отже, одним 3 центральних у дослідженні явища $є$ компаративний метод. Задля з'ясування специфіки акцентності в обраних творах ми порівняли художні особливості інтерпретаційних версій «Трьох поем»: атрибутувати вдалося тільки два аудіозаписи - В. Лютославського / В. Міхнєвського (1976 р.) [10] i Р. Абдулаєва / Ф. Чижевського (2015 р.) [11]; припускаємо, що диригентами 3 третього виконання є А. Віт / А. Стошак [9]; виконавців четвертої версії встановити не вдалося, тому ми називаємо іiі умовно «невідомий колектив» [12]. Також ми проаналізували виконавські прочитання Віолончельного концерту: В. Лютославського / М. Ростроповича [5], Ф. Вельзер-Мьос / I. Мозер [6]; В. Лютославського / Йо-Йо-Ма [7]; Г. Шиффа / Б. Вайнмайстера [8]. Через зіставлення інтерпретаційних версій вдалося з'ясовувати деякі особливості виконавського донесення специфіки акцентної організації, закладеної в тексті партитури. Це відображено в результатах дослідження, де наводяться приклади з виконавських версій «Трьох поем» в інтерпретації А. Віта/А. Стошак [9] та невідомого колективу [12]. Крім цього, задля вирішення сформульованих завдань були також застосовані структурний, системний та функціональний методи.

В обраних творах, відповідно до слухового досвіду, якісна відмінність акцентів зумовлюється, насамперед, ступенем чіткості їх прояву. А відтак, акценти можуть бути виразними, оформленими, кристалічними (с фо ку с о в а н и и ) і невиразними (р о з и и и м и), дія яких відчувається, проте момент стає невловимим, слабким і непомітним. С фо к у с о в ан и й акцент функціонує у двох формах: як п о о ди н о к й в межах самостійних мелодичних побудов та як сумарний, що утворюється за рахунок нашаровування атак всередині фактурних шарів та пластів. Охарактеризуємо особливості функціонування кожного 3 типів, відштовхуючись від аналізу музичного матеріалу. 
Чіткий вияв поодинокого точкового акценту притаманний i аперіодичним ритмічним структурам, i, навпаки, періодичній або рівномірно регулярній організації. Такий тип функціонує в межах виокремлених, самостійних мелодичних ліній фактури через дію чітких атак, узгоджених у часі. Наприклад, в епізоді 3 Віолончельного концерту в цц. 14-15 підкреслення мають певний розподіл у часовій тканині, утворюються в умовах прозорого багатоголосся, в межах регулярного чергування однакових за часовим обсягом та ритмічним малюнком групувань (див. Приклад № 1). У такому разі акцентом $\epsilon$ найбільш виразний, «важкий» звук, а момент виділення має оформлений, точковий вияв. Подібні властивості спостерігаємо в музичному матеріалі 3 цц. 49-55, який є зразком чіткої тактованої метричної регулярності. В побудові 3 цц. 12-13 акценти виникають в умовах нерівномірнорегулярного чергування неоднакових, проте близьких за часовим обсягом групувань. «Місцеположення» найбільш виразної точки є відносним, його можливо визначити лише через контекстуальне порівняння кожного 3 моментів атаки в межах конкретної побудови за ступенем «важкості».

Приклад № 1

Фрагмент із цц. 14-15 Віолончельного концерту

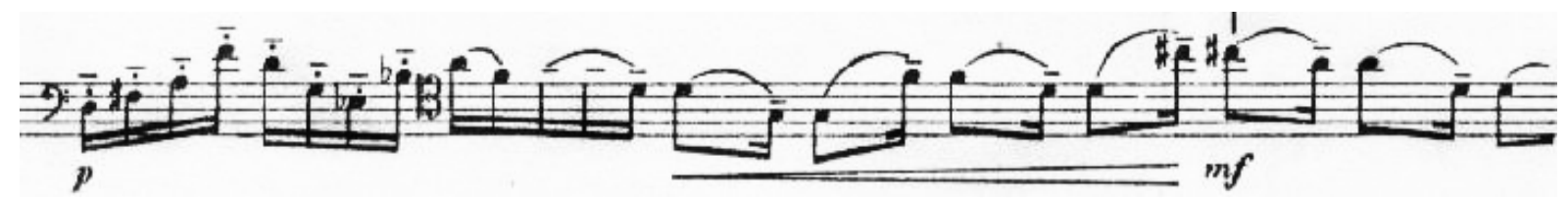

Сумарний точковий акцент формується усередині фактурних шарів та понадбагатоголосних пластів. Неодмінною умовою його утворення $є$ чіткість атак, які $\epsilon$, проте, н е узгоджен и м и у часі . Наприклад, у ц. 52 з ІІ ч. «Трьох поем» одночасно проголошуються на fortissimo шістнадцять рядків поетичного тексту на тлі оркестру. В межах кожної партії утворюються точкові акценти. Але через те, що ритмічні одиниці різних голосів не збігаються в спільному моменті часу, слух сприймає неузгоджену взаємодію самостійних ліній 3 комплексним ефектом «с у м а р н о го » акценту (див. Приклад № 2). Також такий тип акцентності утворюється і за протилежних динамічних умов. Наприклад, вербальний текст в секції цц. 57-66 (II ч. «Трьох поем») в сонорних пластах вимовляється переважно пошепки; акцентоутворюючими засобоми стають: виразне промовляння музично-поетичного тексту, шерхотіння шумних та дзвінких дрижачих приголосних, спеціальне підкреслення кожного останнього складу слова артикуляційним акцентом (>). 
Приклад № 2

\section{Фрагмент із ц. 52 II ч. «Трьох поем»}

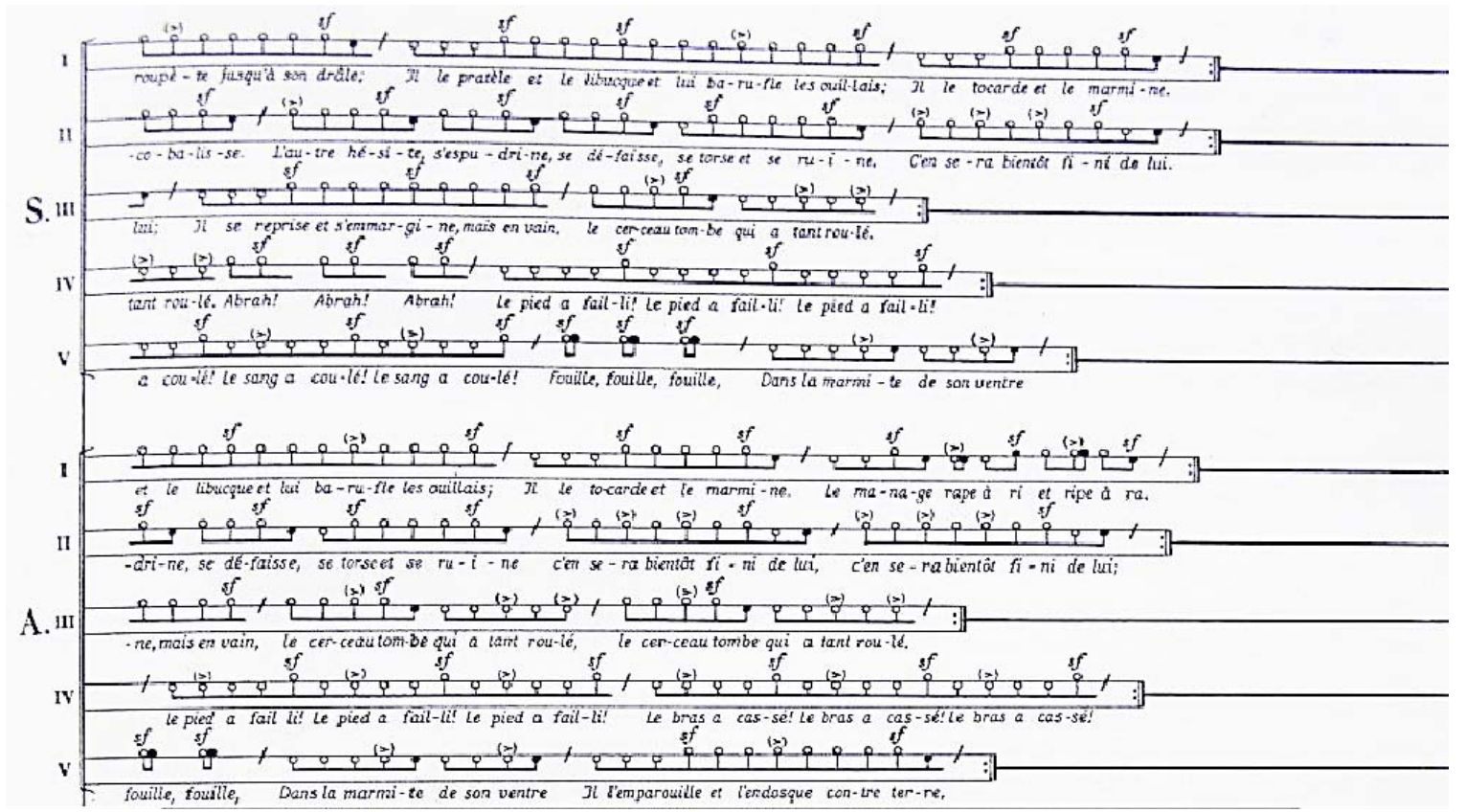

Р о з м и т и й тип акценту в композиціях, які аналізуються, формується усередині фактурних шарів та пластів, «монолітних», «статичних» мікротонових темброзвучностей сонорного типу. Розмиття акцентної точки утворюється через мікроінтервальні ковзання в мелодичній лінії за умов рухливого темпу, недостатньої розчленованості тонів, «ланцюгової», «м'якої» атаки звуку, невеликої гучності, плавної «динамічної хроматизації», глісандування. Приміром, у побудові в ц. 28 з І ч. (див. Приклад № 3) «Трьох поем» у виконанні під орудою А. Віта / А. Стошак [9] хоровий спів має дуже м'які, малопомітні атаки звуку всередині алеаторичного багатоголосся, через що створюється ефект інертного, майже статичного часового континууму (подібними є приклади 3 ц. 154 та ц. 162 I ч. «Трьох поем»).

Приклад № 3

Фрагмент із ц. 28 I ч. «Трьох поем»

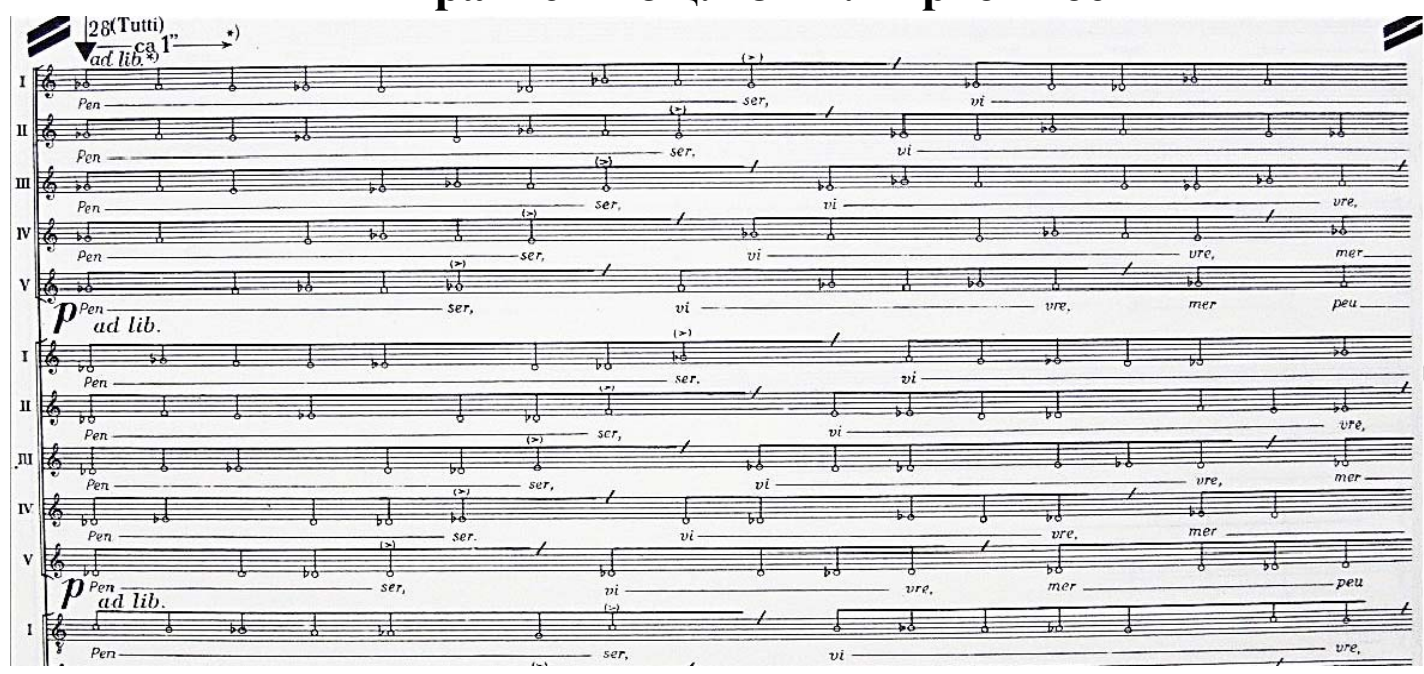


У межах однієї побудови може відбуватися модуляція від розмитого до точкового типу акцентності (та навпаки), або ж - поліфон ічне суміщення дї̈ обох типів. Приміром, епізод 3 ц. 4 та ц. 5 з III ч. «Трьох поем» (див. Приклад № 4) починається синхронним унісонним співом жіночих голосів, якому притаманна точкова акцентність (епізод виконується під керівництвом диригента). Поступово голоси розгалужуються та метрично розбалансуються. Перехрещення півтонових, нецезурованих ковзань на pianissimo створюють легкий звуковий оболок, який вуалює атаки звуку. Відбувається поступова модуляція від точкової до розмитої акцентуації. У цц. 20-24 з III ч. «Трьох поем» кількість голосів поступово збільшується від п’яти до двадцяти. На відміну від попередніх прикладів, секція $\epsilon$ керованою диригентом, а часові співвідношення між тривалостями - чітко визначеними. У фрагменті безперервно утворюються точкові атаки, які мають об’ємний звуковий шлейф. Спочатку в межах кожної партії чітко вимовляється вербальний текст, потім - виспівуються тільки окремі склади слів в межах вузького хроматичного звукоряду. Через вокалізацію голосних звук ніби набуває різної форми: вузької («і»), об’ємної, прямої («а»), глибокої («он»), широкої («е»). Поступове crescendo та збільшення кількості голосів посилює «в’язкість» звуків та їх нерозчленованість у часі.

Приклад № 4

\section{Фрагмент із ц. 5 III ч. «Трьох поем»}

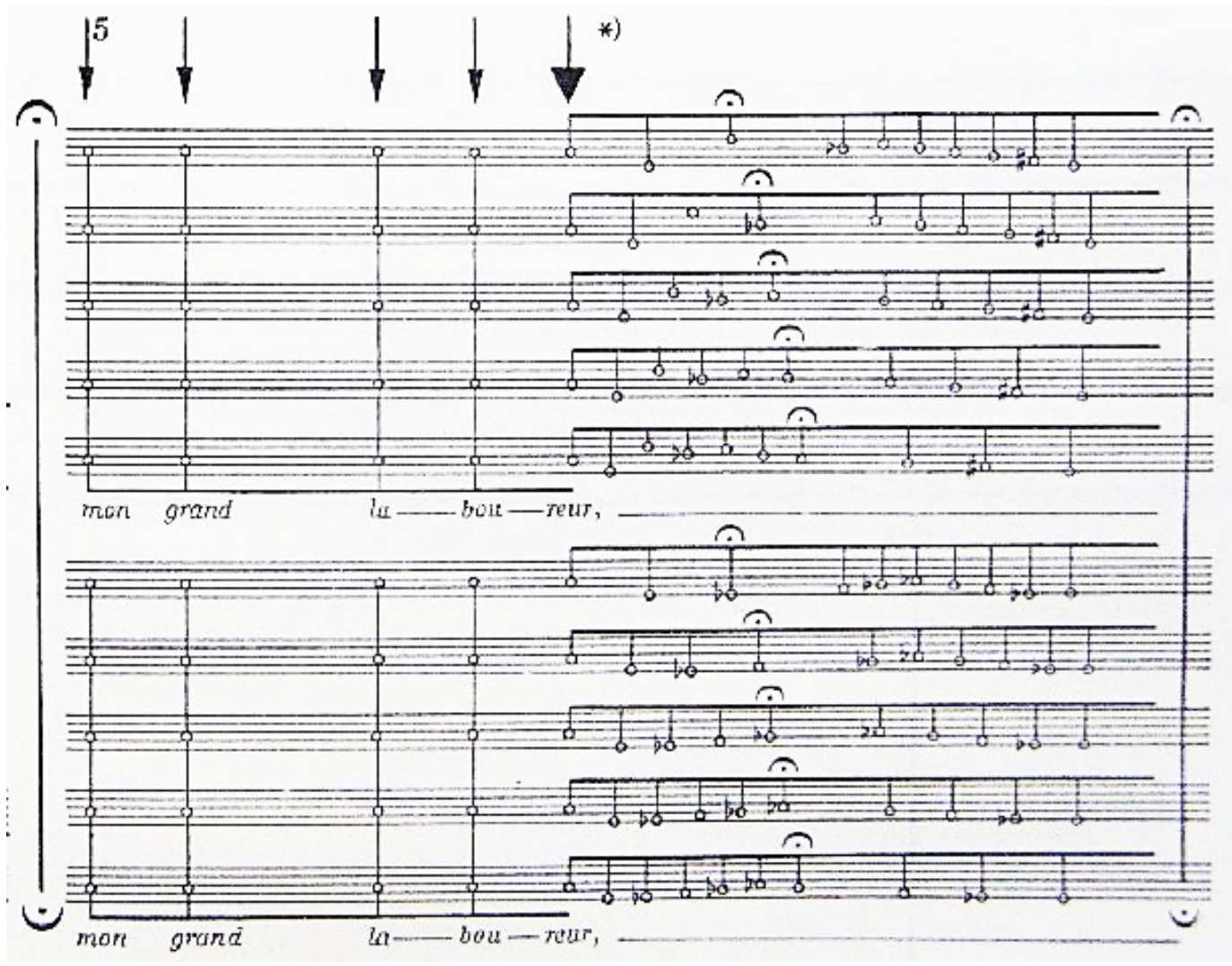


У Віолончельному концерті в цц. 76-77 в партіях струнних синхронно сполучаються розмитий тип акцентуації (у фактурному шарі струнних) та точковий (матеріал солюючої віолончелі). Партії струнних мають «мобільну» акцентну організацію: відбувається поступовий перехід від розмитої акцентності до точкової. У такий спосіб утворюється ефект стрімкого звуження звукового простору, здійснюється перехід до активної пульсації, а відтак - значно динамізується загальний розвиток.

У ц. 6 з III ч. «Трьох поем» півтонові коливання, невелика гучність, поліфонічний тип викладу в партіях жіночих голосів хору сприяють згладжуванню «контурів» акценту та формуванню ефекту часової статики. Утворюється ефект переливчастості голосних, які виспівуються, мають різну тривалість подовження, відмінні артикуляційні наголоси, асинхронно

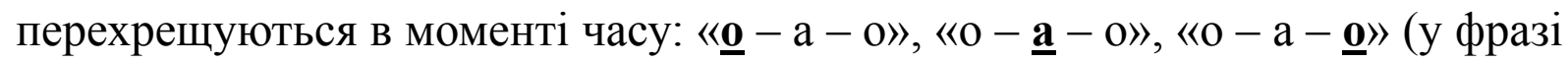
«Le Malheur»), утримуючись в межах двох звуковисотних позицій: «f» та «ges». Власне на таке тло нашаровуються репліки солюючих голосів, які мають чіткі, точкові атаки. У такий спосіб водночас поліфонічно функціонують розмитий та точковий типи акцентуації.

У результаті аналізу композицій вдалося 3'ясувати, що чинники утворення точкового та розмитого акцентів $є$ відмінними. Серед факторів формування точкового акценту насамперед - елементи та засоби музичної мови, які відмічені В. Холоповою. Проте особливої актуальності в творах Лютославського набувають і композиційні чинники. За умови ритмічної нерегулярності та аперіодичності утворення точкового акценту спричинюється дією всезагальних формотворчих принципів повторення (синтаксичних структур із ідентичним внутрішнім устроєм) та оновлення (викладу музичного матеріалу). А саме, точковий акцент, в межах нерегулярності, вирізняється на слух особливо чітко в момент появи нового тематичного матеріалу, фактурної формули, гармонічного комплексу, тембру, динамічного відтінку або - внаслідок ритмо-мелодичного, фактурного повторення, введення подібного за викладом музичного матеріалу.

Крім цього, новим, додатковим акцентоутворюючим засобом стає інструментовка вербального тексту: через шерхотіння та шипіння приголосних формується окремий легкий шар точкових атак. А саме, в ц. 28 з I ч. «Трьох поем» шиплячі приголосні м'яким шлейфом оповивають багатоголосний спів, який має малопомітні, «розмиті» атаки звуку, та утворюють додатковий шлейф сумарних акцентів, слабких, розпорошених, неузгоджених у часі. Проте, приклад 3 ц. 28 I ч. «Трьох поем» у різних виконавських версіях має відмінні якості точкової акцетності. В аудіозаписі невідомого колективу всі шиплячі приголосні $€$ 
дуже чіткими в артикуляції хористів, добре прослуховуються, натомість у виконанні під орудою А. Віта / А. Стошак [9] ці звуки $\epsilon$ абсолютно непомітними. Як результат, у першій з зазначених виконавській версії фрагменту спостерігається поліфонічне поєднання розмитої та сумарної акцентуації, у другій - функціонує тільки розмитий тип.

3'ясувалося, що факторами «розмитого» акцентування в умовах мікрополіфонічного сонорного плетива $\epsilon$ : найвищій ступінь фактурного ущільнення голосів, регістрового розширення або звужування, динамічної та агогічної «хроматизації», а також - відтінення близьким за забарвленням тембром. Ці засоби $\epsilon$ об'єктивними чинниками формування суперечливого феноменун наявності акцентуації в так званих позакцентних умовах, тобто в таких побудовах, де немає багатокількісної появи чітких атак, точок та точних підкреслень. Отже, утворення акценту необов'язково спричинюється початков им моментом звуков идо бування: виділення може сформуватися поступово.

Через те, що підкреслення $\epsilon$ наявним в музичній тканині проаналізованих творів, проте має різні та особливі форми, ми не застосовуємо термін, запропонований В. Холоповою, - «безакцентність» 1 . По-перше, дослідниця наголошує, що це поняття $є$ умовним, тому що акцентуація не може бути відсутньою в музиці. По-друге, дефініція адресується до абсолютно інакшої за ритмічною якістю музики, якій притаманна точкова акцентність (згідно з запропонованою в цій розвідці класифікацією) різних форм та різної, ще до кінця не з'ясованої природи утворення (Д. Шостакович, К. Дебюссі, знаменний розспів тощо). Тобто, термін В.Холопової не $є$ зручним для характеристики ритміки творів В. Лютославського, проте скеровує увагу на проблемну зону в області ритміки, яку необхідно вивчати. Це є подальшою перспективою нашого дослідження.

Отже, ступінь оформленості акценту має в творах різні градації, що зумовлюється якісними властивостями музичного матеріалу та, передусім, - його фактурним викладом.

Вияв нових форм акценту та їх аналіз дозволяє говорити про такі власти в ості явища, які $\epsilon$ актуальними власне для матеріалу композицій Лютославського. А саме, акцент може мати не тільки певну тяжкість, вагу (як це зазначається побіжно в працях Н. Афоніної), а й ступінь напруження, який $\epsilon$ індикатором дії явища. Пропонуємо цією

\footnotetext{
${ }^{1}$ Безакцентність - поняття, запропоноване В. Холоповою стосовно музики знаменних фіт, знаменного розспіву, деяких типів російської протяжної пісні, окремих композицій Д. Шостаковича, К. Дебюссі тощо [8; 9].
} 
дефініцією умовно позначити специфічну якість акценту, яка $\epsilon$ результатом різного ступеня концентрації енергї̈ ${ }^{1}$ в одиниці часу внаслідок виділення ритмічної одиниці. Завдяки розмиттю та вуалюванню точного моменту акценту, утворюється не точка напруження, а зона через поступові динамічні посилення та послаблення, агогічні пришвидшення та уповільнення, фактурне ущільнення та розрідження, регістрове розширення та звужування за умови неодмінної гармонічної, фактурної, ритмо-мелодичної однорідності. Власне через різний ступінь напруження, а не тяжкості, акценти виявляють більшу або меншу інтенсивність власної дії, яка зумовлює можливість тяжіння ритмічних одиниць до об’єднання в цілісність. Напруження як властивість акценту є недослідженим в музикознавстві феноменом. Ми намагаємося пояснити його природу та особливості дії, проте усвідомлюємо, що наведені вище положення потребують ще ретельного осмислення та уточнень.

Напруження точкового акценту $€$ значним: завдяки чіткій оформленості, значній важкості такий тип $\epsilon$ основою утворення функціональних співвідношень сильного та слабкого часу в умовах метричної регулярності, а поза тактометричною системою - квазітактових структур синтаксичного рівня мотиву, фрази (наприклад, цц. 11-13 з Концерту).

Коли ступінь напруження акценту є слабким, ритмічні одиниці дуже слабко тяжіють до об'єднання, сукупно фактично не утворюють квазітактову цілісність, формують відчуття пульсації, хвилі якої не мають акцентованих точок, проте асоціюються, радше, 3 плямами, відтінками м'якого оболоку. Відповідно, вагу, важкість розмитого акценту неможливо чітко диференціювати за шкалою «сильний» - «слабкий».

Отже, аналіз нових форм акценту дозволяє дійти висновку, що засаднича, атрибутивна властивість цього елементу - короткочасність - в позаметричних умовах отримує нову якість. А саме, акцент має різну тривалість розповсюдження власної дії, яка є відносною, нестабільною й залежить від ступеня напруження та важкості. Ця властивість $є$ неодмінною складовою змісту явища в композиціях, які аналізуються.

Можна підсумувати, що акцент в обраних творах $\epsilon$ автономним ритмічним елементом у разі природнього його функціонування в рівномірно-регулярних епізодах та результативним в умовах нерівномірної

\footnotetext{
${ }^{1}$ Це поняття застосовується радше як метафора: енергія акценту як наслідок різного ступеня інтенсивності виділення ритмічної одиниці. Виміряти цей феномен та визначити його кількісне значення не можна, проте оминути своєю увагою його дію також неможливо.
} 
регулярності, аперіодичності ${ }^{1}$. Результативність явища спричинюється залежністю його утворення та виявлення в композиціях Лютославського, як зазначалося, від властивостей музичного матеріалу. А саме, переважно лише через контекстуальне співставлення точок та зон концентрації енергії в певному фрагменті можна визначити факт формування акцентуточкового чи розмитого - та визначити його «місцеположення».

Отже, пропонуємо схематичний опис властивостей акценту як явища:

\section{Властивості явища акценту в творах В. Лютославського}

Загальні та атрибутивні:

- комплексність;

- незмірність;

- короткочасність;

- різна, відносна міра ваги (важкості);

- різний ступінь напруження (сильний, слабкий);

Специфічні:

- різні форми та різний ступінь чіткості вияву акценту;

- можливість модуляційного переходу від однієї форми акцентності до іншої;

- можливість синхронної взаємодії різних форм акцентності;

- відносна тривалість розповсюдження дії напруження;

- тяжіння ритмічних одиниць до об'єднання у цілісність через дію напруження.

Крім цього, на оформленість акценту впливають не тільки якості та властивості музичного матеріалу. Ступінь чіткості атак зумовлюється також конкретним виконавським втіленням : артикуляцією, шв идкістю виконання, яка впливає на ступінь розчленованості тонів, кількісним складом виконавців та технічною якістю аудіозапису. Також усвідомлення специфіки акцентності залежить від фактору індивідуального слухацького сприйняття : від кількості прослуховувань, часового обсягу обраної слухом побудови, активного чи пасивного спрямування уваги на акцентуацію. Цей чинник $\epsilon$ найбільш проблемним у вивченні явища та спричинює необхідність подальшого дослідження акценту під кутом зору психології сприйняття.

У результаті аналізу вдалося виявити, що функція точкових акцентів (і поодиноких, i сумарних) полягає у формуванні через їх дію

\footnotetext{
1 Застосовуємо термінологію, запропоновану Т. Бершадською [3] в теорії ладу, тому що принципи автономності та результативності, визначені дослідницею, сягають універсального рівня.
} 
відчуття розгалуженої, різноманітної за відтінками та градаціями ак т и в н о ї, динамічної пуль с а цї̈. 3 гладжування акцентованих точок $\epsilon$ фактором утворення художнього ефекту слабко пульсуючого, статичного часового плину. Крім цього, акцент $\epsilon$ одним 3 чинників формування відчуття на слух явищ поліритмії, політемповості, поліхронності. Політемп відчувається за умови синхронної взаємодії виокремленої лінії солюючого голосу та багатоголосного комплексу, що мають дуже контрастні рівні ритмічних тривалостей (тип акценту в політемпових побудовах не є визначальним). По лір и т і я утворюється за умови нашарування фактурних ліній, що мають точковий тип акценту. П о л і х р о н н і с т ь виникає у разі суміщення в фактурних лініях, шарах та пластах дії точкової та розмитої акцентуації, через що створюється ефект поєднання інертного та динамічного плинів (ілюстрацією може послугувати приклад 3 ц. 6 III ч. «Трьох поем», проаналізований раніше).

Явище «розмиття» акценту спостерігається в багатьох творах інших композиторів новітнього часу. Наприклад, такий тип функціонує в окремих побудовах в «Іонізаціях» Е. Вареза, «Атмосферах», «Lux aeterna» Д. Лігеті, «Uaxuctum» Дж. Шельсі, «Metastasis» Я. Ксенакіса, Симфонії № 3 А. Тертеряна, «Plainscapes» Я. П. Васкса, Concerto Grosso № 1, «Pianissimo» А. Шнітке, «Open spaces» Г. Ф. Хааса, «Тринадцяті кольорах сонця, що сідає» Т. Мюрая тощо - творах, абсолютно відмінних за технікою композиції. Незвичним під кутом зору співвідношення різних типів акцентності є, на наш погляд, твір «Іонізації» Е. Вареза. Полічасовий ефект створюється завдяки нашаруванню неметризованих партій двох сирен на поліритмічний пласт ударного оркестру. В музичному матеріалі сирен напруження концентрується не в моменті часу, а в зоні, на яку припадає посилення гучності та зміна висоти звучання. Формування розмитої акцентуації відбувається тут в межах не фактурного шару або пласта, а двох самостійних мелодичних ліній. У такому випадку через розмиту акцентуацію не утворюється ефект часової статики, притаманної асинхронному багатоголосному плетиву. Проте, сполучення часових плинів ударних та сирен формує яскравий ефект поліхронності, поєднання різних часових плинів. Тож, можна попередньо підсумувати, що феномен розмитої акцентуації не пов'язаний з конкретною технікою композиції.

Отже, визначення форм акцентності в обраних творах (сфокусованої, розмитої) зумовлюється, передусім, властивостями музичного матеріалу, а також - особливостями звукової реалізації тексту партитури. Головним елементом змісту акценту $\epsilon$ 
підкреслення, засоби якого є дуже різноманітними. Зокрема, особливого значення в умовах нерегулярності набувають всезагальні формотворчі принци повторення та оновлення, які є чинниками точкової акцентуації. Додатковим фактором $\epsilon$ також інструментовка вербального ряду. Абсолютно недослідженими $є$ чинники формування акценту в позаакцентних умовах - сонорних понадбагатоголосних фактурних утвореннях. Вияв, визначення та аналіз зазначених форм акцентності дозволяють з'ясувати й функції явища. Окрім об'єднання та роз'єднання часового потоку, акцент $\epsilon$ фактором утворення квазітактової чарунки в умовах нерегулярності, звукової плями, м'якого оболоку в середині сонорного пласта, чинником виникнення багаторівневої пульсації, а також - утворення художніх ефектів ритму-статики та ритму-динаміки, полічасових структур. Завдяки проведеному аналізу, можна говорити й про нові властивості акценту. А саме, окрім комплексності та незмірності, важкості, короткочасності дії, акцент має певний ступінь напруження сильний та слабкий, а напруження, своєю чергою, - відносну, нестійку тривалість розповсюдження. Визначений комплекс властивостей дозволяє говорити про подвійну природу явища акценту - акцент як енергію та акцент як ритмічну одиницю. До «енергетичних» властивостей належать напруження та тяжкість, структурних - форми вияву явища. Головним висновком нашого дослідження $\epsilon$ те, що акцент в творах Лютославського може мати різні форми функціонування - автономну в умовах метричної регулярності та результативну в межах нерегулярних побудов.

Визначення в результаті дослідження комплексу нових, актуальних для композицій В. Лютославського форм акцентності (точкова та розмита), доповнення сучасних теоретичних положень характеристикою окремих властивостей явища (напруження та різна тривалість розповсюдження його діï), функцій (акцент як фактор утворення художніх явищ часової організації, а також - пульсації, тактових та квазітактових цілісних чарунок) зумовлює наукову новизну дослідження.

1. Афонина Н. Ю. Ритм, метр, темп : временная организация в музыке. СанктПетербург : Союз художников, 2003. $48 \mathrm{c}$.

2. Афонина Н. Ю. Ритмический рисунок : уч. пос. по дисциплине «Ритмический практикум» / Санкт-Петербургская гос. конс. им. Н. А. Римского-Корсакова. СанктПетербург, 2017. 172 c.

3. Бершадская Т. С. Лекции по гармонии. Ленинград : Музыка, 1985. 236 с.

4. Должанский А. Н. Краткий музыкальный словарь. Изд. 5-е. Москва ; Ленинград : Музыка, 1966. 518 с. 
5. Лютославський В. Концерт для віолончелі з оркестром : аудіозапис / диригент: В. Лютославський ; соліст: М. Ростропович. URL: http://classic-online.ru/downloads/ ?file_id=79140 (дата звернення: 28.11.2017).

6. Лютославський В. Концерт для віолончелі 3 оркестром : аудіозапис / диригент: Ф. Вельзер-Мьось ; соліст: I. Мозер. URL: http:/classic-online.ru/downloads/?file $\mathrm{id}=77395$ (дата звернення: 28.11.2017).

7. Лютославський В. Концерт для віолончелі з оркестром : аудіозапис / диригент: В. Лютославський ; соліст: Йо-Йо-Ma. URL: http:/classic-online.ru/downloads/?file_ $\mathrm{id}=165473$ (дата звернення: 28.11.2017).

8. Лютославський В. Концерт для віолончелі з оркестром : аудіозапис / диригент: Г. Шифф ; соліст: Б. Вайнмайстер. URL: http://classic-online.ru/downloads/?file $\mathrm{id}=29861$ (дата звернення: 28.11.2017).

9. Лютославський В. Три поеми Анрі Мішо : аудіозапис / диригенти - А. Віт, A. Стошак. URL: http://classic-online.ru/downloads/?file_id=149789 (дата звернення: 28.04.2018).

10. Лютославський В. Три поеми Анрі Мішо : аудіозапис / диригенти В. Лютославський, В. Міхнєвський. 1978. URL: http://classic-online.ru/downloads/ ?file_id=126131 (дата звернення: 28.11.2017).

11. Лютославський В. Три поеми Анрі Мішо : аудіозапис / диригенти - Р. Абдулаєв, Ф. Чіжевський URL: https://www.youtube.com/watch?v=AXMhc3RkxEs (дата звернення: 26.03.2019).

12. Лютославський B. Три поеми Анрі Мішо : аудіозапис / Невідомий виконавець. URL: http://classic-online.ru/downloads/?file_id=20761_(дата звернення: 28.04.2018).

13. Музыкальный энциклопедический словарь / гл. ред. Г. В. Келдыш. Москва : Сов. энциклопедия, 1990. 672 с.

14. Риман Г. Музыкальный словарь / ред., пер. с нем., доп. Ю. Энгеля. Москва ; Лейпциг : Издательство П. Юргенсона, 1900. 1536 с.

15. Українська музична енциклопедія. Т. 1 : А-Д / гол. редкол. Г. Скрипник. Київ : Ін-т мистецтвознавства, фольклористики та етнології ім. М. Т. Рильського НАН України, 2006. $679 \mathrm{c}$.

16. Холопова В. Н. Теория музыки : мелодика, ритмика, фактура, тематизм. СанктПетербург : Лань, 2002. 368 с.

17. Холопова В. Н. Вопросы ритма в творчестве композиторов первой половины ХХ века. Москва : Музыка, 1971. 304 с.

18. Encyclopedia muzyki / pod red. A. Chodkowskiego. Drugie wyd. Warszawa: Wydawnictwo Naukowe PWN, 2001. $1126 \mathrm{~s}$.

19. London D. Rhythm // The New Grove Dictionary of Music and Musicians : CD-ROM : in 29 vol. / eds. S. Sadie, J. Tyrrel. New York : Grove Oxford University Press, 2001.

20. The New Grove Dictionary of Music and Musicians: CD-ROM: in 29 vol./ eds. S. Sadie, J. Tyrrel. New York : Grove Oxford University Press, 2001.

21. The New Grove Dictionary of Music and Musicians : in 20 vol. Vol. 15 : PlayfordRiedt / edited by S. Sadie. London : Macmillan Publishers Limited, 1995. 866 p. 


\section{References}

1. Afonina, N. (2003). Rhythm, metrum, tempo: the temporal organization in music. St. Petersburg : Soyuz hudozhnikov [in Russian].

2. Afonina, N. (2017). The rhythmic pattern. St. Petersburg: Sankt-Peterburgskaya gosudarstvennaya konservatoriya im. N. A. Rimskogo Korsakova [in Russian].

3. Bershadskaya, T. (1971). Lectures on Harmony. Leningrad : Muzyka [in Russian].

4. Dolzhanskiy, A. (1996). Concise dictionary of music. Moscow; Leningrad: Muzyka [in Russian].

5. Lutosławski, W. (n.d.). Three poemes by Henri Michaux. [online] Available at: http://classiconline.ru/downloads/?file_id=126131 [Accessed 28 November 2017] [in Russian].

6. Lutosławski, W. (n.d.). Three poemes by Henri Michaux. [online] Available at: https://www.youtube.com/watch?v=AXMhc3RkxEs [Accessed 28 November 2017] [in Russian].

7. Lutosławski, W. (n.d.). Three poemes by Henri Michaux. [online] Available at: http://classic-online.ru/downloads/?file_id=149789 [Accessed 28 April 2018] [in Russian].

8. Lutosławski, W. (n.d.). Three poemes by Henri Michaux. [online] Available at: http://classic-online.ru/downloads/?file_id=20761 [Accessed 28 April 2018] [in Russian].

9. Lutosławski, W. (n.d.). Cello Concerto. [online] Available at: http://classiconline.ru/downloads/?file_id $=79140$ [Accessed 28 November 2017] [in Russian].

10. Lutosławski, W. (n.d.). Cello Concerto. [online] Available at: http://classiconline.ru/downloads/?file_id=77395 [Accessed 28 November 2017] [in Russian].

11. Lutosławski, W. (n.d.). Cello Concerto. [online] Available at: http://classiconline.ru/downloads/?file_id=165473 [Accessed 28 November 2017] [in Russian].

12. Lutosławski, W. (n.d.). Cello Concerto. [online] Available at: http://classiconline.ru/downloads/?file_id=29861 [Accessed 28 November 2017] [in Russian].

13. Keldyish, G. (Ed.). (1990). Encyclopedic dictionary of music. Moscow: Sovetskaya entsiklopediya [in Russian].

14. Riemann, H. (1900). Dictionaty of music. Moscow : Izdatelstvo P. Yurgensona [in Russian].

15. Skrypnyk, H. (2006). (Ed.). Ukrainian encyclopedia of music. Vol. 1. Kyiv : Instytut mystetstvoznavstva, folklorystyky ta etnolohii im. M. T. Rylskoho NAN Ukrainy [in Ukrainian].

16. Holopova, V. (2002). The theory of music: melody, rhythm, texture, thematism. St. Petersburg : Lan [in Russian].

17. Holopova, V. (1971). The issues of the rhythm in the works of composers of the first half of the XX century. Moscow : Muzyika [in Russian].

18. Chodkowski, A. (Ed.) (2001). The encyclopedia of music. Warsow: Wydawnictwo Naukowe PWN [in Polish].

19. London, D. (2001). Rhythm. In: The New Grove Dictionary of Music and Musicians. S. Sadie, J. Tyrrel (Ed.). New York : Grove Oxford University Press [in English].

20. Sadie, S., Tyrrel, J. (Eds.). (2001). The New Grove Dictionary of Music and Musicians. New York : Grove Oxford University Press [in English].

21. Sadie, S. (Ed.). (2001). The New Grove Dictionary of Music and Musicians. Vol. 15. London : Macmillan Publishers Limited [in English]. 